


\title{
Ocean Tower at Alys Beach, Florida
}

\section{Ocean Tower en Alys Beach, Florida}

\author{
Ocean Tower em Alys Beach, Flórida
}

As a planned New Urban community, Alys Beach was designed as a dense town center along a broad white-sand beach. The location of this project's parcel not only offered an architecturally prominent location on the urban space named Gulf Green, but also was critical to the town's urban plan. The form-based code required building to the street on the two sides of the corner where the building stands and dictated a 4-story element on this corner lot. This was intended to create a "gateway" from the sea to the town. As the country's first "Hurricane Hardened Community”, it also dictated that the four story structure be built of masonry and to the highest level of storm fortification.

\footnotetext{
$<$ Details of the buttresses and wooden elements | Detalles de los contrafuertes y elementos de madera Pormenores dos contrafortes e elementos em madeira (Richard Powers)

$>$ Location of the building on Gulf Green, Alys Beach | Ubicación del edificio en Gulf Green, Alys Beach | Implantação do edifício em Gulf Green, Alys Beach
}

\section{Michael G. Imber, Architects}

La comunidad de Alys Beach, planificada conforme a los modelos del Nuevo Urbanismo, fue diseñada como un centro urbano denso a lo largo de una amplia playa de arena blanca. El emplazamiento de la parcela de este proyecto no sólo ofrecía una ubicación arquitectónicamente destacada en el espacio urbano denominado Gulf Green, sino que también era fundamental para el plan urbanístico de la ciudad. La normativa requería edificar en la alineación de la calle por ambos lados de la esquina en la que se sitúa e imponía un cuerpo de cuatro plantas eta parcela de esquina. Se buscaba crear con ello una "puerta" de acceso desde el mar hacia la localidad. Como primera "Comunidad Reforzada frente a Huracanes” del país, la normativa también dictaba que la estructura de cuatro plantas se construyera con fábrica y con el grado más alto de refuerzo frente a tormentas.
A comunidade de Alys Beach, planificada conforme os modelos do Novo Urbanismo, foi concebida como um centro urbano denso ao longo de uma ampla praia de areia branca. A localização da parcela deste projecto não só ofereceu uma localização arquitectonicamente proeminente em Gulf Green, como também foi crucial para o plano urbano da cidade. As normas requeriam a construção em ambos os lados da rua, e ditavam um elemento de quatro andares no lote da esquina, criando uma "porta de entrada” do mar para a cidade. Na qualidade de primeira "Comunidade fortalecida contra furacões” do país, as normas ditavam também que a estrutura de quatro andares fosse construída em alvenaria e ao mais alto nível de fortificação contra tempestades.

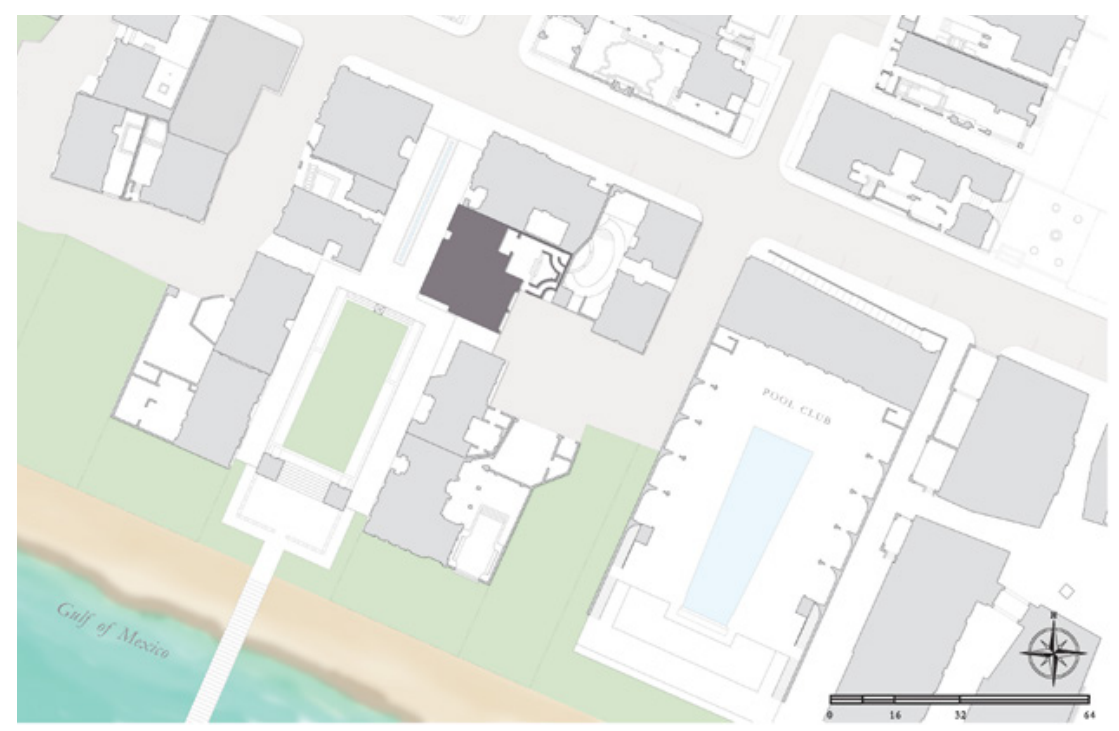




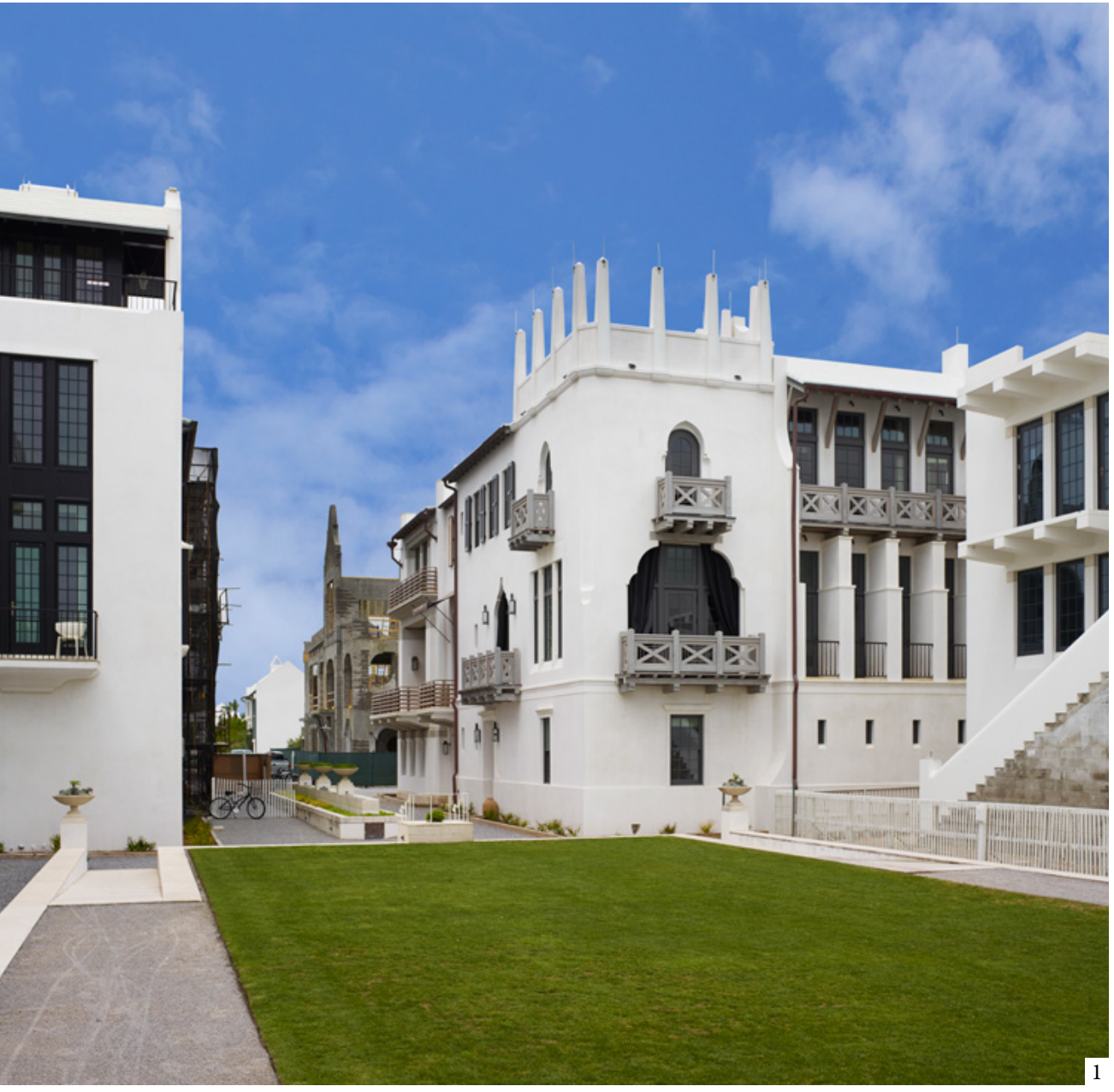

1: The corner buildings forming a "gateway" from the sea to the town 2: Openings and balconies on the corner tower | 1: Los edificios de las esquinas forman una "puerta" desde el mar a la ciudad 2: Aberturas y balcones en la torre de la esquina | 1: Os edifícios de gaveto formam uma "porta" desde o mar à cidade 2: Vãos e varandas na torre de gaveto (1 and 2: Richard Powers)

The massing dictated by the code, along with the all-white aesthetic of Alys Beach, left us with a block from which we were to derive the articulation, a deductive process of design, similar to that of a sculptor carving from a block of white marble.

Although Alys Beach's aesthetic as a community was heavily influenced by that architecture of the Bahamas and, more importantly for us, Antigua, Guatemala, we were interested in reaching further back for our precedent. Our interests in the very early influences on that architecture of Central America went as far back to the Mediterranean while it was under the influence of Rome and to the root of early Roman vernacular architecture of Southern Spain, Tunisia and other provinces.
La forma dictada por la normativa, junto con la estética totalmente blanca propia de Alys Beach, nos dejaba un bloque que debíamos articular por medio de un proceso deductivo de diseño similar al de un escultor tallando un bloque de mármol blanco.

Aunque la estética de Alys Beach como comunidad estaba fuertemente influida por la arquitectura de las Bahamas y, de manera más importante para nosotros, por la de Antigua, Guatemala, estábamos interesados en llegar más lejos en busca de precedentes. Nuestro interés por las primeras influencias de esa arquitectura de América Central se remontan al Mediterráneo, al tiempo en que estuvo bajo la influencia de Roma y a la raíz de la arquitectura vernácula romana temprana en el sur de España, Túnez y otras

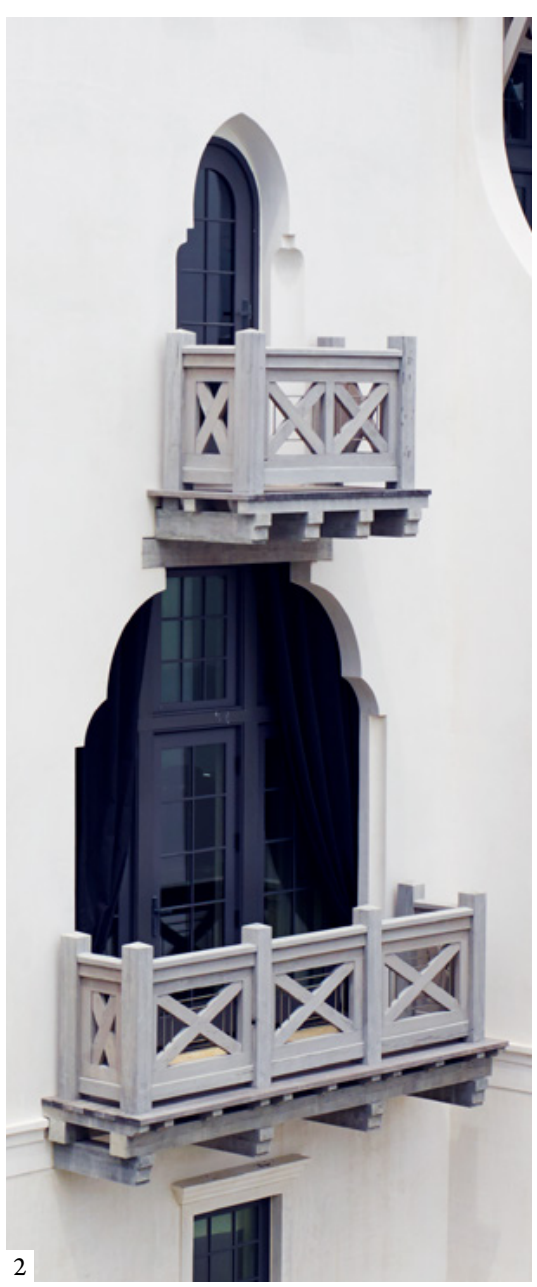

A forma ditada pelas normas, juntamente com a estética totalmente branca de Alys Beach, deixou-nos com um bloco que deveria ser articulado com um processo dedutivo de desenho semelhante ao de um escultor esculpindo a partir de um bloco de mármore branco.

Embora a estética de Alys Beach como comunidade tenha sido fortemente influenciada pela arquitectura das Bahamas e, mais importante para nós, de Antígua, Guatemala, foi do nosso interesse recuar ainda mais em busca do nosso precedente. $\mathrm{O}$ nosso interesse nas primeiras influências sobre essa arquitectura da América Central remontou ao Mediterrâneo enquanto se encontrava sob a influência de Roma, e à raiz da arquitectura vernacular romana inicial do Sul de Espanha, Tunísia e outras províncias que 
Those places form the foundation and spirit of that architecture.

Masonry and concrete construction were expressed purely as white mass, while elements such as railing, windows and doors were all expressed in contrast as simple wood elements. An exotic air to the language was achieved through simple straight-forward tectonics, while avoiding literal historic references. provincias. Esos lugares componen los cimientos y el espíritu de esa arquitectura.

La construcción de fábrica y hormigón se manifestaba puramente como una masa blanca, mientras que elementos como barandillas, ventanas y puertas contrastaban con ella en forma de sencillos elementos de madera. Se logró un aire exótico en el lenguaje a través de una tectónica simple y directa, evitando las referencias históricas literales. constituem a fundação e o espírito dessa arquitectura.

A construção em alvenaria e betão foi puramente expressa como uma massa branca, enquanto que elementos como corrimões, janelas e portas foram todos expressos, em contraste, como simples elementos de madeira. Alcançou-se uma linguagem com um ar exótico com recurso a uma tectónica simples e directa, ao mesmo tempo que foram evitadas as referências históricas literais.
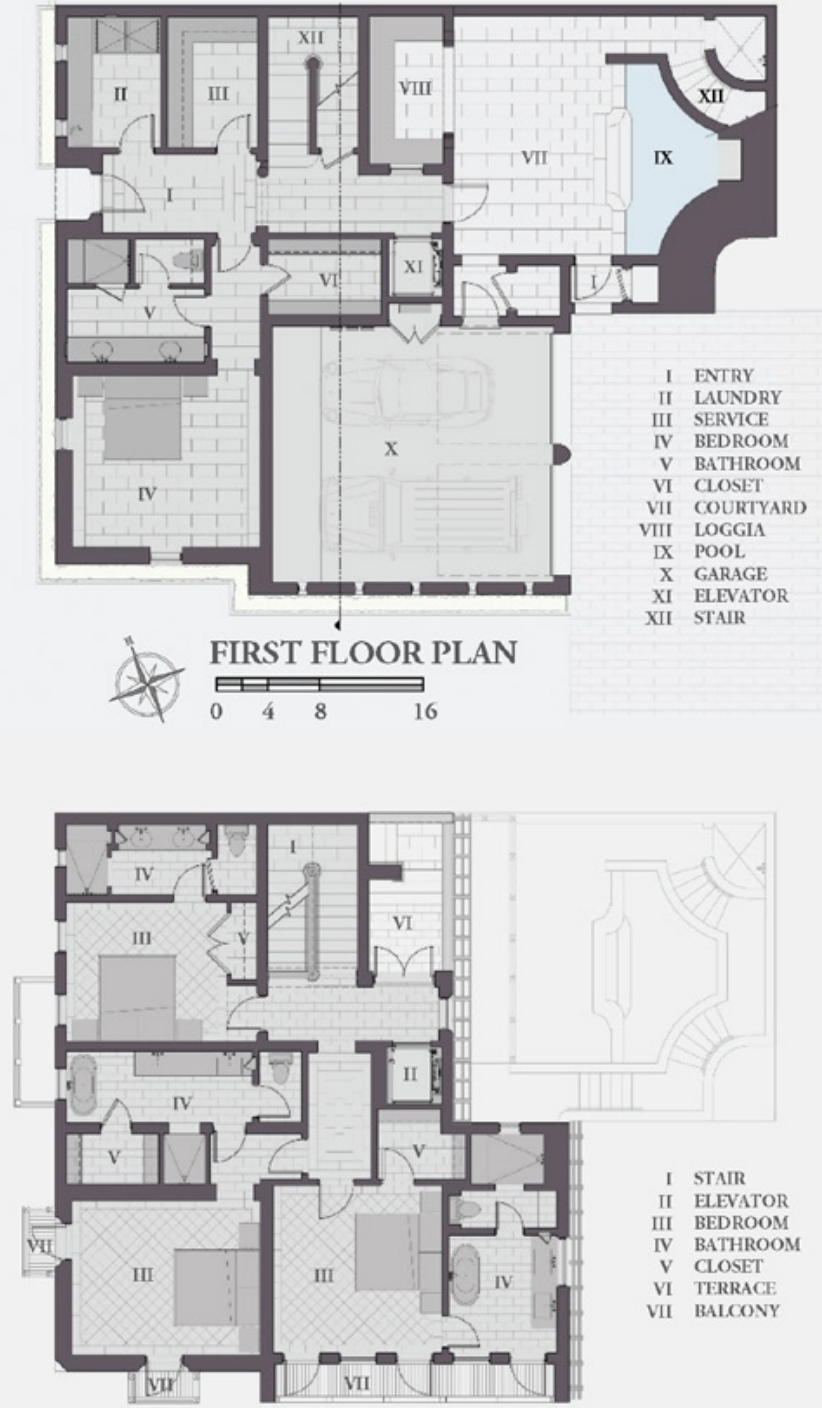

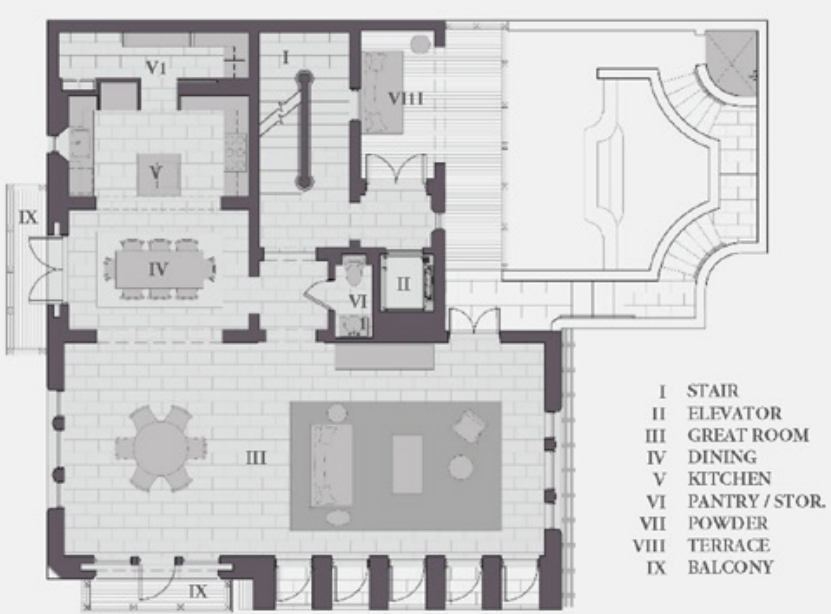

SECOND FLOOR PLAN

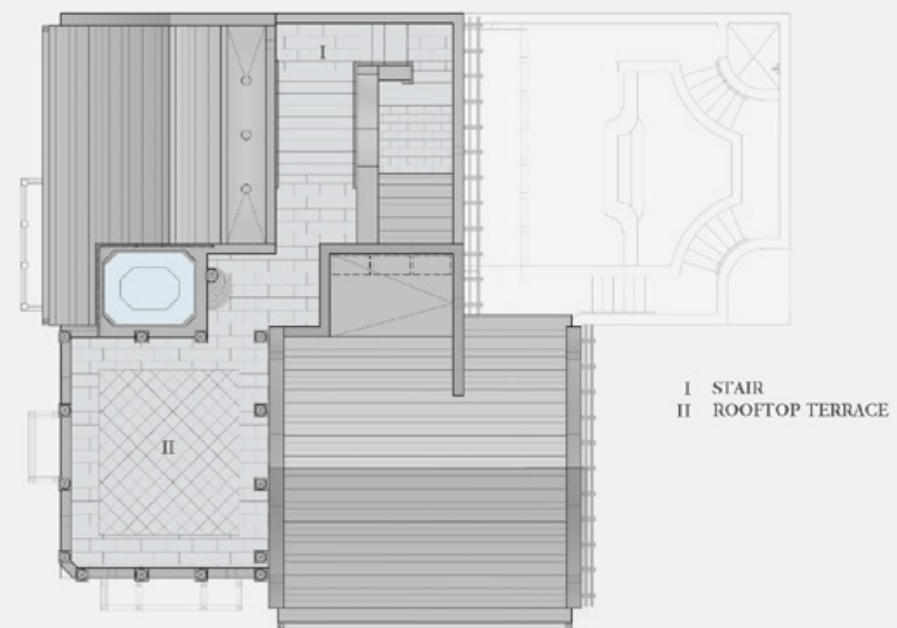




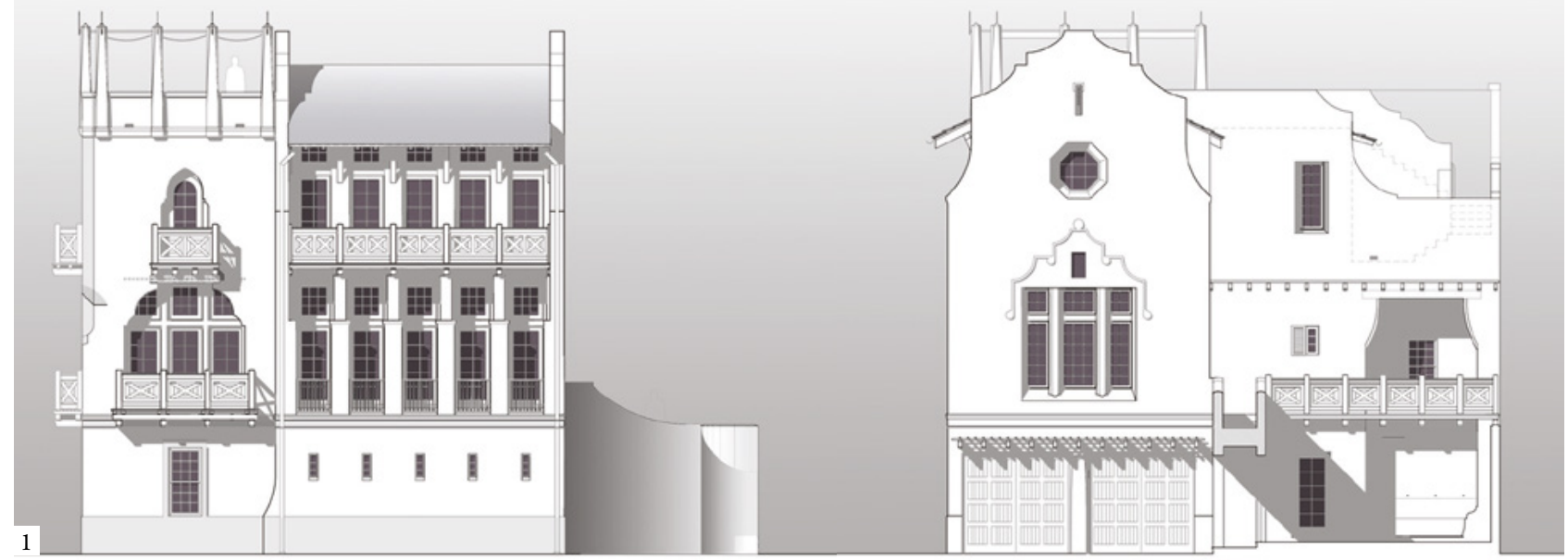

1: Elevations of the Ocean Tower 2: Exterior of the building from the court 3: The terrace overlooking the Gulf of Mexico 4 and 5: Pool and outdoor shower | 1: Alzados de la Ocean Tower 2: Exterior del edificio desde el patio 3: La terraza con vistas al Golfo de México 4 y 5: Piscina y ducha exterior | 1: Alçados da Ocean Tower 2: Exterior do edifício desde o pátio 3: Varanda com vistas para o Golfo de México 4 e 5: Piscina e duche exterior (2, 3, 4 and 5: Richard Powers)

Albeit, the 4,000 sf (approximately $372 \mathrm{~m}^{2}$ ) residence was fitted onto an impossibly small 50' x 50' (15 meters $\mathrm{x} 15$ meters) lot for the program required. Space was carved out to be as experiential as possible, drawing one up, around and through the light-filled block, always to a view and, eventually, the tower overlooking the sea. Elements such as the buttresses of the piano noble
La residencia, de aproximadamente 372 metros cuadrados (4,000 pies cuadrados), se situó en una parcela de 15 metros x 15 metros (50' x 50'), increíblemente pequeña para el programa requerido. El espacio fue "tallado" para hacerlo lo más experiencial posible, para llevar a uno por encima, alrededor y a través de ese bloque lleno de luz, siempre orientado hacia una vista $y$, finalmente,
A residência de aproximadamente 372 metros quadrados (4000 pés quadrados) foi inserida num lote extremamente pequeno de 15 x 15 metros (50' x 50') para o programa requerido. $\mathrm{O}$ espaço foi "esculpido" de forma a ser o mais experiencial possível, levando-nos para cima, em redor e através do bloco iluminado, sempre até uma vista e, eventualmente, até à torre com vista para o mar. Elemen-
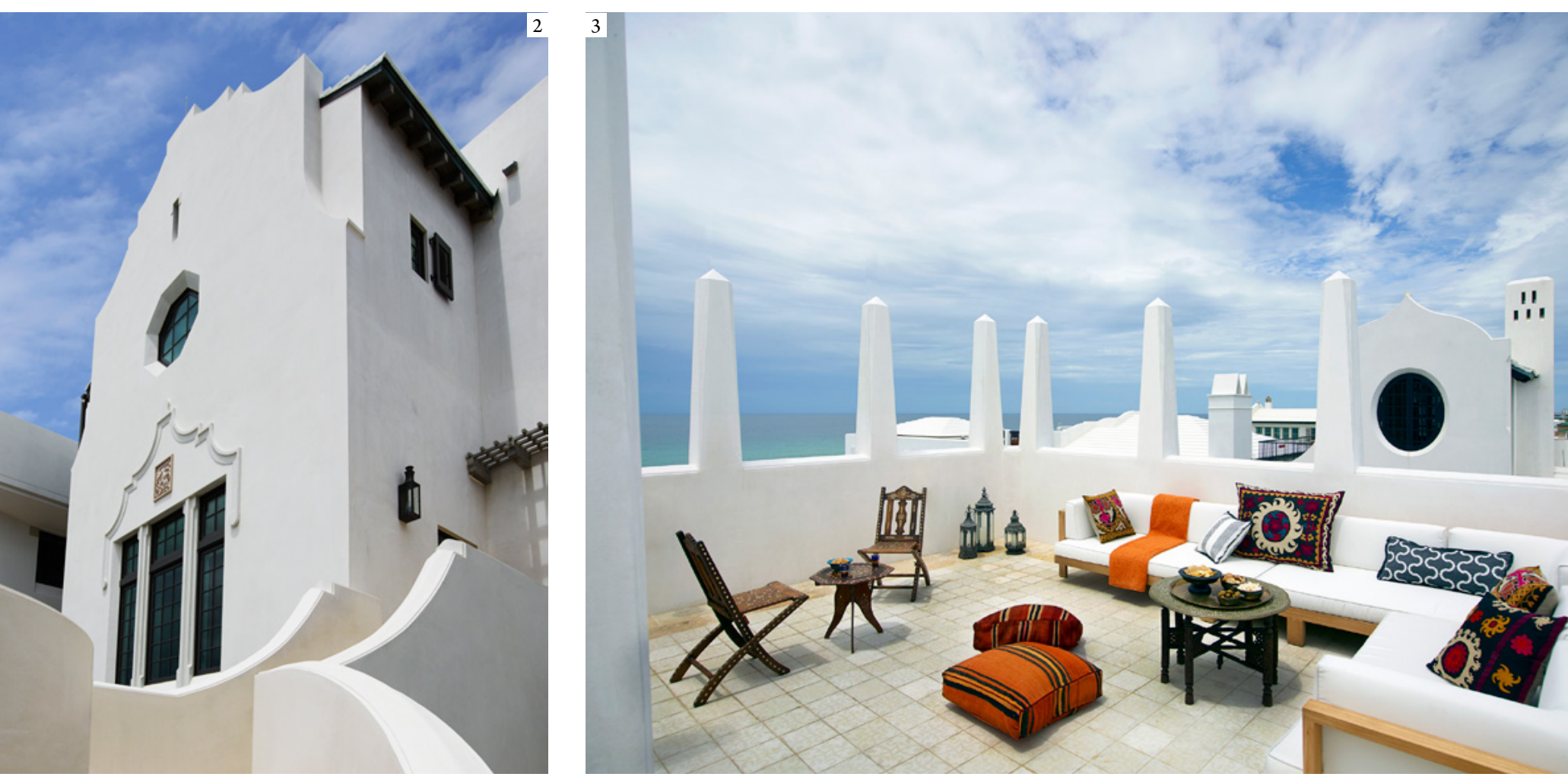

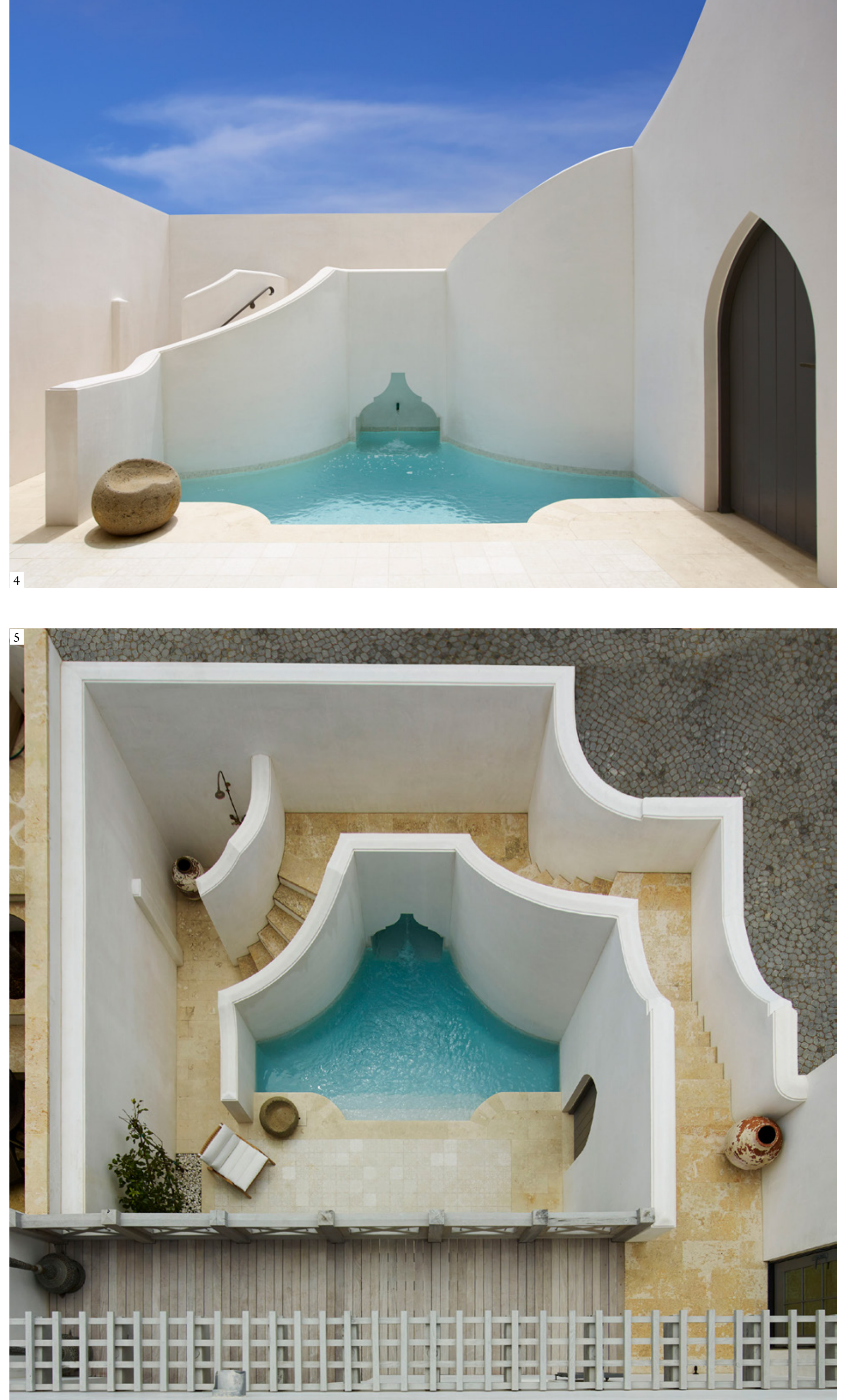
not only block the intense Florida sun, but also radiate light into the interior space, illuminating the materials within. Sinker cypress recovered from a nearby river was used for timber railings and the timber roof structure. This cypress was also used for refined interior finishes, such as millwork, providing a soft warm contrast to the white plaster of the interior. conduciéndolo hacia la torre que domina el mar. Elementos como los contrafuertes de la planta principal no solo bloquean el intenso sol de Florida, sino que también irradian luz al espacio interior, iluminando los materiales de dentro. El ciprés sinker, recuperado de un río cercano, fue utilizado para las barandillas y la estructura de madera del techo. Este ciprés también se utilizó para los acabados interiores más refinados, como los elementos decorativos de madera, proporcionando un contraste suave $y$ cálido con el enlucido blanco del interior. tos tais como os contrafortes do piso principal não só bloqueiam o intenso sol da Flórida, como também irradiam luz sobre o espaço interior, iluminando os materiais que ali se encontram. Foi utilizado cipreste sinker recuperado de um rio nas proximidades nos corrimões de madeira e na estrutura de madeira do telhado. Este cipreste foi também utilizado nos acabamentos interiores refinados, como a carpintaria, proporcionando um contraste suave e quente ao reboco branco do interior.

1, 2 and 3: Interior spaces 2: Exterior living area | 1, 2 y 3: Espacios interiores 2: Sala de estar abierta al exterior 1,2 e 3: Espaços interiores 4: Sala de estar aberta para o exterior (1, 2 ,3 and 4 Richard Powers. Interior design by Lynn Myers of Lynn Myers Designs)
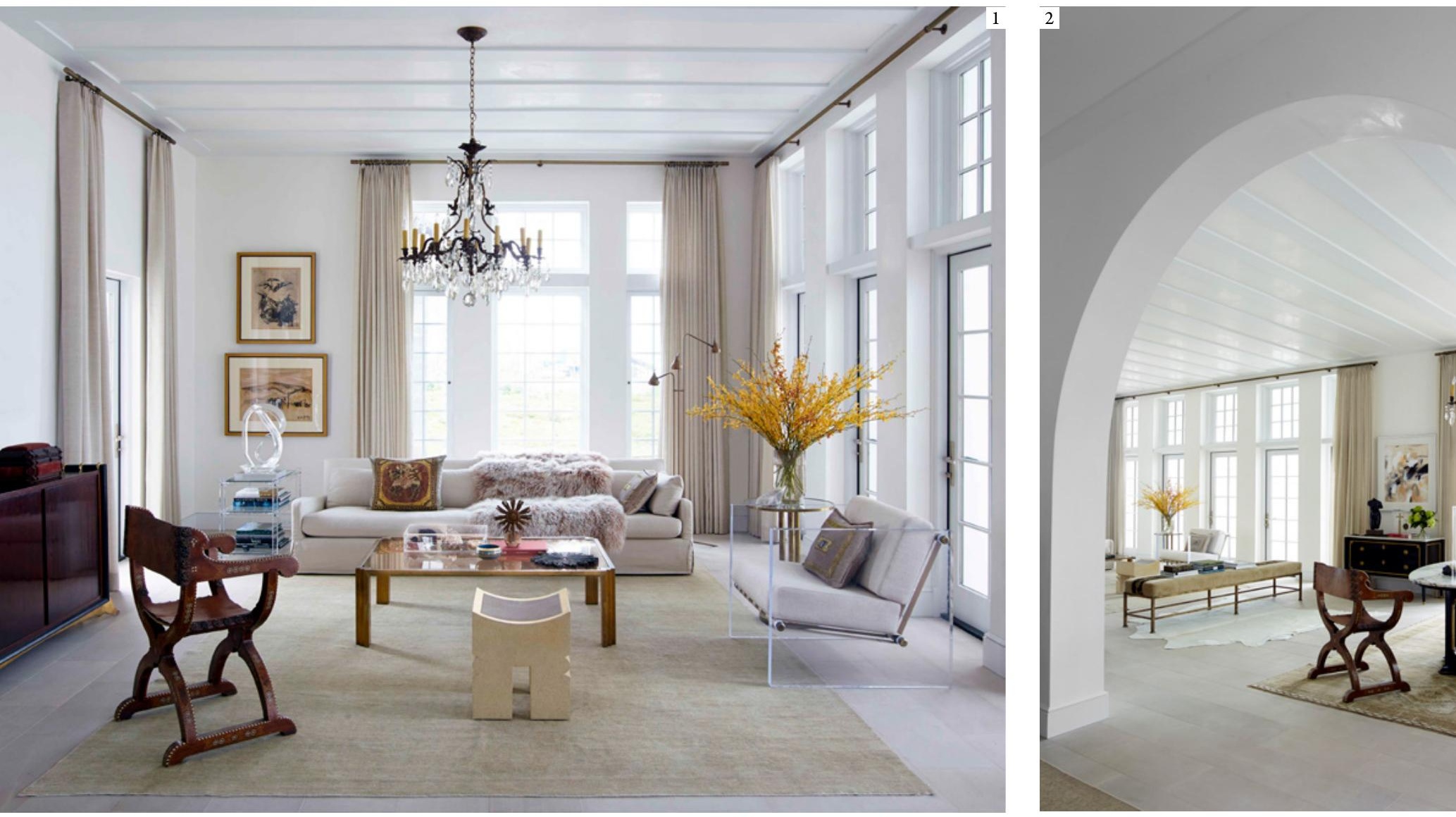


\section{Michael G. Imber}

He is the principal architect of Michael G. Imber, Architects, PLLC, a modern classical design firm based in San Antonio, Texas. Michael G. Imber, Architects are known for their work's response to unique and varied places, landscapes and cultures. Michael has been honored with numerous local and national design awards, notably being honored with the lifetime Arthur Ross Award and four Palladio Awards - the only national award for excellence in traditional design in America. He was inducted into the American Institute of Architects' College of Fellows as well as being honored with the Texas Society of Architects' William W. Caudill, FAIA award for his achievements as a young architect and for his contributions to the American Institute of Architects.

Es el arquitecto director de Michael G. Imber, Architects, PLLC, un estudio de diseño clásico moderno en San Antonio, Texas. Michael G. Imber, Architects son conocidos por la respuesta que da su trabajo a lugares, paisajes y culturas únicos y variados. Michael ha sido galardonado con numerosos premios de diseño locales y nacionales, y ha recibido el Arthur Ross Award por su trayectoria y cuatro Palladio Awards, el único premio nacional americano a la excelencia en el diseño tradicional. Fue nombrado miembro del College of Fellows del American Institute of Architects y galardonado con el William W. Caudill, FAIA Award de la Texas Society of Architects por sus logros como joven arquitecto y sus contribuciones al American Institute of Architects.

É o arquitecto principal da Michael G. Imber, Architects, PLLC, uma empresa moderna de desenho clássico sediada em San Antonio, Texas. A Michael G. Imber Architects é conhecida pelo seu trabalho que dá resposta a lugares, paisagens e culturas únicas e variadas. Michael tem sido condecorado com numerosos prémios de desenho local e nacional, nomeadamente com o vitalício Arthur Ross Award e quatro Palladio Awards - o único prémio nacional de excelência em desenho tradicional na América. Foi integrado no College of Fellows do American Institute of Architects, bem como condecorado com o William W. Caudill, FAIA Award da Texas Society of Architects pelos seus resultados alcançados como jovem arquitecto, e pelas suas contribuições para o American Institute of Architects.
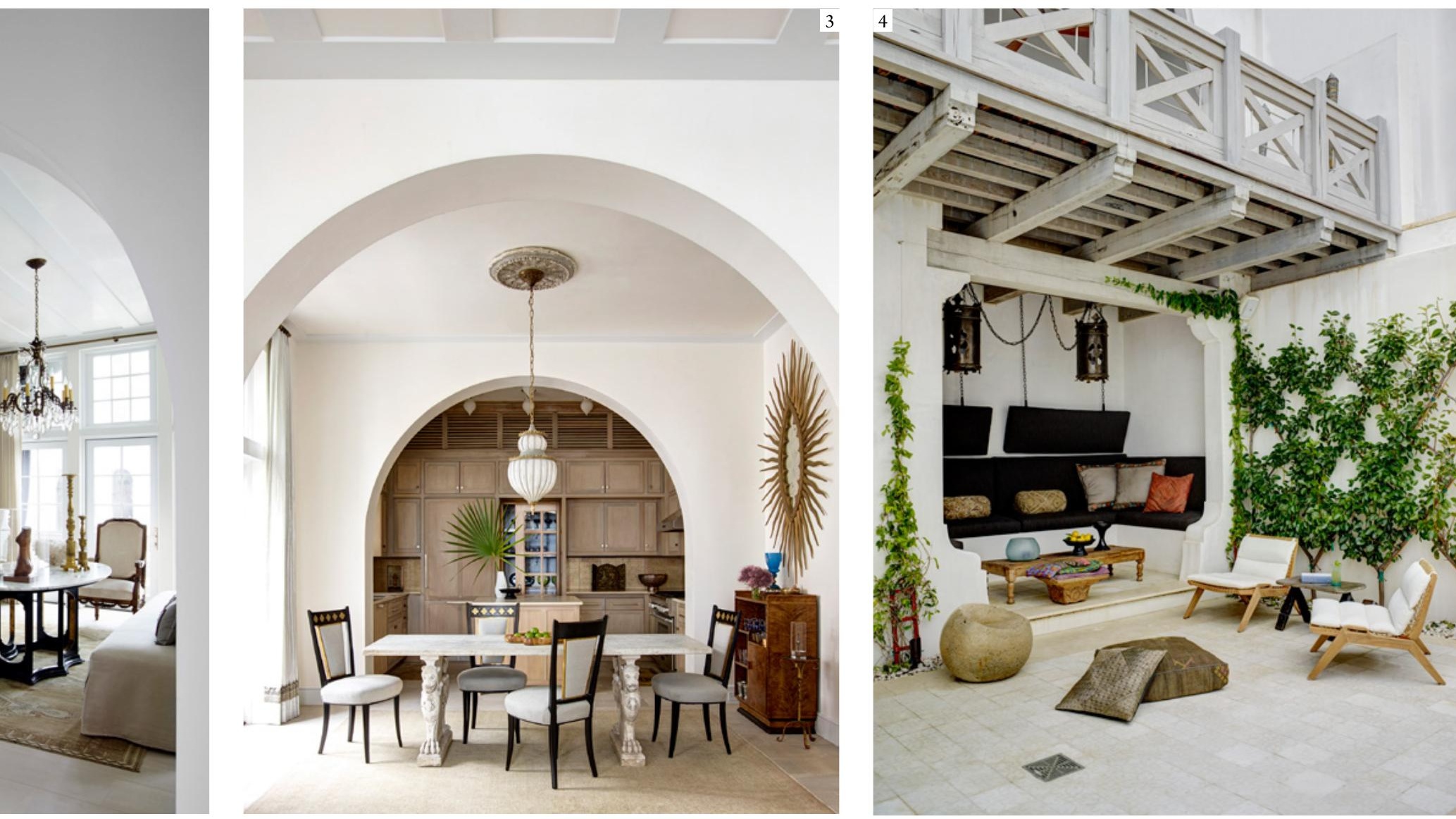